\title{
Correction to: Temporal trends of contaminants in Arctic human populations
}

\author{
Khaled Abass $^{1,2}$ (D) $\cdot$ Anastasia Emelyanova $^{3}$ - Arja Rautio $^{1,3}$
}

Published online: 25 May 2019

(C) The Author(s) 2019

\section{Correction to: Environmental Science and Pollution Research (2018) 25:28834-28850 https://doi.org/10.1007/s11356-018-2936-8}

The article Temporal trends of contaminants in Arctic human populations, written by Khaled Abass, Anastasia Emelyanova and Arja Rautio, was originally published electronically on the publisher's internet portal (currently SpringerLink) on 25 August 2018 without open access.

With the author(s)' decision to opt for Open Choice the copyright of the article changed on May 2019 to $\odot$ The Author(s) 2019 and the article is forthwith distributed under the terms of the Creative Commons Attribution 4.0 International License (http://creativecommons.org/licenses/by/4.0/), which permits use, duplication, adaptation, distribution and reproduction in any medium or format, as long as you give appropriate credit to the original author(s) and the source, provide a link to the Creative Commons license and indicate if changes were made.

Open Access This article is distributed under the terms of the Creative Commons Attribution 4.0 International License (http://creativecommons.org/licenses/by/4.0/), which permits use, duplication, adaptation, distribution and reproduction in any medium or format, as long as you give appropriate credit to the original author(s) and the source, provide a link to the Creative Commons license and indicate if changes were made.

Publisher's note Springer Nature remains neutral with regard to jurisdictional claims in published maps and institutional affiliations.

The online version of the original article can be found at https://doi.org/ 10.1007/s11356-018-2936-8

Khaled Abass

khaled.megahed@oulu.fi; khaled.m.abass@gmail.com

1 Arctic Health, Faculty of Medicine, University of Oulu, P.O. Box 5000, FI-90014 Oulu, Finland

2 Department of Pesticides, Menoufia University, P.O. Box 32511, Menoufia, Egypt

3 Thule Institute \& University of Arctic, University of Oulu, Oulu, Finland 